Baseline

\title{
Spatial variations in trace element concentrations of the sea urchin, Paracentrotus lividus, a first reference study in the Mediterranean Sea
}

\author{
Ternengo S. ${ }^{\mathrm{a}, \mathrm{b}, *}$, Marengo M. ${ }^{\mathrm{a}, \mathrm{c}}$, El Idrissi O. ${ }^{\mathrm{a}, \mathrm{b}}$, Yepka J. ${ }^{\mathrm{c}}$, Pasqualini V., ${ }^{\mathrm{a}, \mathrm{b}}$, Gobert S. ${ }^{\mathrm{c}, \mathrm{d}}$ \\ ${ }^{a}$ Université de Corse Pascal Paoli, UMR 6134 CNRS-UCPP Sciences pour l'Environnement, 20250 Corte, France \\ ${ }^{\mathrm{b}}$ Université de Corse Pascal Paoli, UMS 3514 CNRS-UCPP Plateforme marine Stella Mare, 20620 Biguglia, France \\ ${ }^{c}$ Université de Liège, Centre MARE, Focus, Laboratoire d'Océanologie, Sart-Tilman, B6c, 4000 Liège, Belgium \\ ${ }^{\mathrm{d}}$ STAtion de REcherche Sous-marines et Océanographiques (STARESO), 20260 Calvi, France
}

\section{A R T I C L E I N F O}

\section{Keywords:}

Paracentrotus lividus

Contamination indicator

Trace Element Pollution Index

Marine pollution

Biomonitoring

Mediterranean Sea

\begin{abstract}
A B S T R A C T
A study on Trace Elements (TE) from sea urchin gonads has been conducted in the western Mediterranean Sea. Contamination data were used to determine a Trace Method Pollution Index (TEPI). TE concentrations varied considerably depending on the location of the sampling stations. The results showed that five trace elements ( $\mathrm{Zn}$, $\mathrm{Fe}, \mathrm{As}, \mathrm{Al}, \mathrm{Cu}$ ) are ubiquitous. The geographical area considered (Corsica) represents an important range of environmental conditions and types of pressure that can be found in the western Mediterranean Sea. TEPI was used to classify the studied sites according to their degree of contamination and allowed reliable comparison of TE contamination between local and international sites. TE contamination of the western Mediterranean Sea displayed a north-to-south gradient, from the Italian coasts down through the insular Corsican coasts to the north African littoral. Due to the increasing environmental pressure on the Mediterranean Sea, a regular monitoring of TE levels in marine organisms is necessary to prevent any further environmental deterioration.
\end{abstract}

Human activities have caused a considerable increase of potentially toxic discharges into the marine environment. This has led to a decline in species diversity and negative consequences for human health (Salomidi et al., 2012; Belabed et al., 2013). The presence of Trace Elements (TE) in marine ecosystems is growing. There are two potential sources of emissions: anthropogenic and naturally occurring (Serrano et al., 2011). Due to their toxicity, persistence, and ability to accumulate in marine organisms, TE are considered a major source of pollution in the marine environment (Bonanno and Di Martino, 2017).

Bioindicators are commonly used to monitor marine environment quality. They allow evaluation of the levels of biologically available contaminants in the environment (Campanella et al., 2001). The concentrations found indicate the type, nature, and exposure time of these contaminants to organisms in the study area (Morrison et al., 2017). Based on this method, many classification tools have been developed to characterize the overall quality of water bodies and the health status of coastal ecosystems (Lopez y Royo et al., 2009; Richir and Gobert, 2014). It turns out that several species have specific criteria used to assess the contamination status of marine ecosystems which makes them good bioindicators (Zhou et al., 2008; Richir and Gobert, 2016). Among them, the sea urchin Paracentrotus lividus (Lamarck, 1816) is considered as a sentinel species. It has often been used as a tool to assess marine pollution of coastal ecosystems (Gharred et al., 2015; Guendouzi et al., 2017; Soualili et al., 2008; Warnau et al., 1998). This marine invertebrate is a relevant biological model for the study of environmental pollution. It is recognized as a bioindicator for several reasons: its ecological relevance, benthic and relatively sedimentary lifestyle, rapid response, and high sensitivity to many types of contaminants (Ruocco et al., 2016; Salvo et al., 2016; Scanu et al., 2015). These qualities allow the comparison of marine TE contamination on both the local and the international scale. The Corsica Island is often considered a pristine region (largely due to its low industrialization rate); the quality of its waters and its low fishing pressure give it a reference site status in the Mediterranean (Galgani et al., 2006; Gobert et al., 2017). However, there is very little data available on pollution levels in this region.

Therefore, the aim of this study was to: (i) assess $20 \mathrm{TE}$ contaminating the Corsican coastline using P. lividus as a bioindicator; (ii) track observed contamination levels to possible sources; (iii) obtain background levels on the local scale and complete existing databases; and (iv) perform intraspecific comparisons with previous worldwide studies (industrialized and non-industrialized areas).

This study was carried out along the Corsican coastline (western Mediterranean Sea) in four coastal areas (Ajaccio, Bonifacio, Calvi, and

\footnotetext{
* Corresponding author at: Université de Corse Pascal Paoli, UMR 6134 CNRS-UCPP Sciences pour l'Environnement, 20250 Corte, France.

E-mail address: ternengo@univ-corse.fr (S. Ternengo).
} 


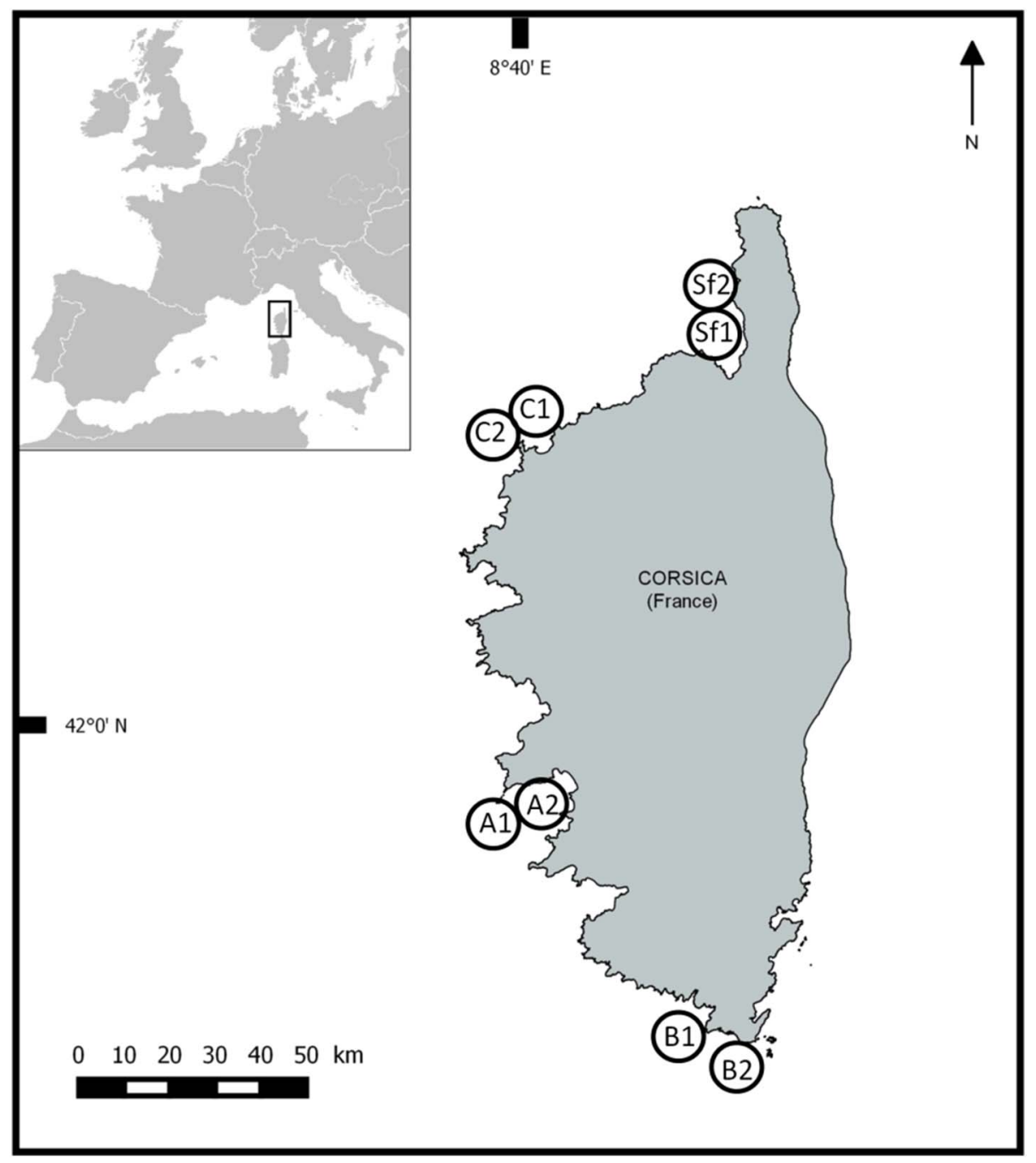

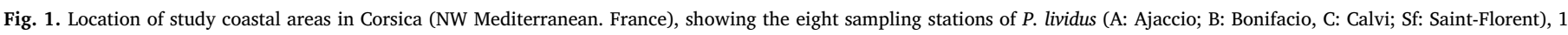
reference site, 2 impacted site.

Saint-Florent) between February and March 2017. In each area, two stations were sampled (Fig. 1).

In view of the possible sources of contamination, the main characteristics used for choosing the sampling zones were differences in types and levels of contamination assumed. The sampling was designed to characterize the coastline in order to compare local values with previously reported data from other Mediterranean areas (Guendouzi et al., 2017; Soualili et al., 2008; Storelli et al., 2001; Warnau et al., 1998). The analysis of this information has contributed to the ranking of sampling sites with regard to the environmental quality. The sampling points were localized to cover several environmental parameters and anthropogenic pressures (wastewater treatment plant, commercial harbor, marina, and a former asbestos mine; Fig. 1).

Divers collected specimens of $P$. lividus from natural populations, with a minimum of fifteen individuals taken at each station, resulting in a total of 120 individuals collected. Until analysis, the gonads were stored at $-20{ }^{\circ} \mathrm{C}$. Gonads were cleaned with ultrapure water before analysis. The samples were mineralized in Teflon digestion vessels, in a closed microwave digestion LabStation (Ethos D. Milestone Inc.), using nitric acid and hydrogen peroxide as reagents (Suprapur ${ }^{\circledR}$ grade, Merck).

Analyses of 20 TE (Ag, Al, As, Ba, Cd, Co, Cr, Cu, Fe, Li, Mn, Mo, Ni, $\mathrm{Pb}, \mathrm{Sb}, \mathrm{Se}, \mathrm{Sn}, \mathrm{U}, \mathrm{V}$, and $\mathrm{Zn}$ ) were determined by Inductively Coupled Plasma Mass Spectrometry using Dynamic Reaction Cell technology (ICP-MS ELAN DRC II, PerkinElmer ${ }^{\circledast}$ ), according to the method described by Richir and Gobert (2014). In order to check the purity of the chemicals used, a number of chemical blanks were run; there was no evidence of any contamination in these blanks. Analytical quality control was achieved using Certified Reference Materials (CRM), DOLT5: Dogfish Liver; DORM-4: Fish protein; NIST 1566b: Oyster; and NIST 2976: Mussel tissue. A high level of agreement was obtained on the certified values for all the TE by the analysis of the CRM (global mean recovery was $92 \pm 14 \%$ ). Noticing that no certified values were reported for $\mathrm{Ba}, \mathrm{Bi}$ and $\mathrm{Sb}$. For each TE, detection limit (LD) and quantification limit (LQ) were calculated, depending on their specific blank distribution (Currie, 1999). The unit used to present our results is expressed in milligrams of element per kilogram of dry weight $\left(\mathrm{mg} \cdot \mathrm{kg}^{-1}\right.$ $\mathrm{dw}$ ). The level of TE contamination for each site was calculated using the Trace Element Pollution Index (TEPI) developed by Richir and Gobert (2014). As recommended for the calculation of the TEPI, the data were standardized by mean normalization. A high TEPI value indicates a potentially polluted site. Unlike the Metal Pollution Index (MPI), the TEPI allows a reliable comparison of study sites, regardless of the type of TE dosed or the biological model used (Richir and Gobert, 2014). TEPI values were calculated using the following formula: TEPI $=\left(C f_{1} * C f_{2} \ldots C f_{n}\right)^{1 / n}$ where $C f_{n}$ is the mean normalized concentration of the TE in each site or station and $n$ is the number of TE examined. A 3-level water quality scale was established, using the quartile method and TEPI values. Based on TEPI values, the quartiles were calculated to determine the class limits of the 3-level water quality 
scale. The three levels of the quality scale were defined based on the values of the upper and lower quartiles: (i) low contamination level (LCL, TEPI values below the first quartile mean), (ii) medium contamination level (MCL, TEPI values between the 1st and 3rd quartile means), and (iii) high contamination level (HCL, TEPI values above the 3rd quartile means) (Morrison et al., 2017; Richir et al., 2015).

Contamination levels for each station were then determined based on the TEPI values. The calculation of the Trace Element Spatial Variation Index (TESVI) makes it possible to compare TE according to the overall spatial variability of their environmental levels according to Richir and Gobert (2014).

For each TE, the TESVI $=\left[\left(x_{\max } / x_{\min }\right) /\left(\Sigma\left(x_{\max } / x_{i}\right) / \mathrm{n}\right)\right] * \mathrm{SD}$ where $x_{\max }$ and $x_{\min }$ are the maximum and minimum mean concentrations recorded among the $n$ sites, $x_{i}$ are the mean concentrations recorded in each of the $n$ sites, and SD is the standard deviation of the mean ratio $\Sigma\left(x_{\max } / x_{i}\right) / \mathrm{n}$. For a given TE, the higher the value of the TESVI, the more its environmental levels will vary globally across the study area (for further details see Richir and Gobert, 2014). To better comply with the conditions of the application of parametric statistical tests, and to bring elemental concentrations within the same range, data were natural-log transformed (Gobert et al., 2017). A one-way analysis of variance (ANOVA) and post-hoc Tukey's Honestly Significant Difference (HSD) tests were used to assess the existence of significant differences between TE concentrations for all stations.

The results of mean TE concentrations in $P$. lividus gonads are presented in Table 1 . There is a very strong variation in the TE concentrations found according to the sampling stations. Significant differences between stations were found for a large number of TE (Table 1). The accumulated levels of TE followed the same sequence $\mathrm{Zn}>\mathrm{Fe}>\mathrm{As}>\mathrm{Al}>\mathrm{Cu}>\mathrm{V}>\mathrm{Mn}>\mathrm{Se}>\mathrm{Cr}>\mathrm{U}>\mathrm{Ni}>$ $\mathrm{Co}>\mathrm{Mo}>\mathrm{Li}>\mathrm{Ba}>\mathrm{Cd}>\mathrm{Pb}>\mathrm{Sb}>\mathrm{Ag}>\mathrm{Sn}$. At all eight sampling stations, $\mathrm{Zn}$ was always the most abundant element; the lowest abundance was always observed for Sn, indicating that $P$. lividus has a higher tendency to accumulate essential TE such as $\mathrm{Zn}, \mathrm{Fe}, \mathrm{Cu}$, and Mn.

For each station, the TEPI was calculated and the values obtained showed a small range of variation. TEPI values ranged from 1.033 at Saint-Florent2 to 0.440 at Calvi1 (Table 2). Based on the TEPI, SaintFlorent 2 was the most contaminated site with the highest levels of Co, $\mathrm{Cr}, \mathrm{Fe}$, and Ni. The high concentrations of these TE seem to influence the TEPI values obtained. Based on the TEPI values calculated for the eight stations studied, three class levels were defined from the quartiles
Table 2

Trace Element Pollution Index (TEPI) of sea urchin P. lividus collected from 8 stations in Corsica Island.

\begin{tabular}{lll}
\hline Stations & TEPI & Local quality scale \\
\hline Ajaccio1 & 0.548 & Low contamination level \\
Ajaccio2 & 0.701 & High contamination level \\
Bonifacio1 & 0.622 & Medium contamination level \\
Bonifacio2 & 0.590 & Medium contamination level \\
Saint Florent1 & 0.621 & Medium contamination level \\
Saint Florent2 & 1.033 & High contamination level \\
Calvi1 & 0.440 & Low contamination level \\
Calvi2 & 0.638 & High contamination level \\
\hline
\end{tabular}

(low, medium, and high contamination) (Table 2).

Three stations were classified as highly contaminated (Ajaccio2, Calvi2, Saint Florent2), three as moderately contaminated (South1, South2, Saint Florent1), and two as slightly contaminated (Ajaccio1, Calvi1) (Table 2).

The results showed that some reference stations, chosen for their apparent non-anthropized zone status, are nevertheless impacted by TE contamination.

The TESVI values obtained ranged from 0.10 to 11.84 (Table 3). Ni was the element that showed the largest spatial variation between sites, with the highest value of TESVI (11.84). The station with the highest average concentration of $\mathrm{Ni}$ in $P$. lividus was Saint-Florent2 $\left(5.25 \pm 1.34 \mathrm{mg} \cdot \mathrm{kg}^{-1}\right)$. Following $\mathrm{Ni}$, only five of the $20 \mathrm{TE}$ examined obtained a TESVI value > 5.0: Ag (9.49), Sn (8.51), Co (5.98), Al (5.55), and $\mathrm{Cr}$ (5.41). Li is the element with the lowest spatial variation between stations (0.10) (Table 3). TESVI values were listed in ascending order as: $\mathrm{Li}, \mathrm{Cu}, \mathrm{Se}, \mathrm{Mo}, \mathrm{Mn}, \mathrm{Zn}, \mathrm{As}, \mathrm{V}, \mathrm{Ba}, \mathrm{U}, \mathrm{Pb}, \mathrm{Fe}, \mathrm{Cd}, \mathrm{Sb}, \mathrm{Cr}$, $\mathrm{Al}, \mathrm{Co}, \mathrm{Sn}, \mathrm{Ag}, \mathrm{Ni}$. The ranking of TE in ascending order of their TESVI values also makes it possible to clearly highlight the TE of key environmental concern.

The results of this study are discussed and compared with those of previously published studies from the Mediterranean Sea. We compiled our data together with the re-calculated TEPI values for other locations around the world to obtain insight into the TE concentration ranges at the global scale, and to place our results in perspective (Fig. 2, Table 4). TE concentrations in gonads are known to vary according to many biological parameters such as sex, age, or season (Hambidge et al., 1986; Unuma et al., 2007); these variables should be taken into account to give a more reliable image of the contamination rates in sea urchin

Table 1

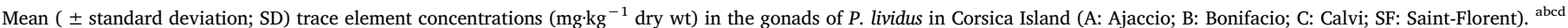
Dissimilar letters denote significant differences between groups $(\mathrm{p}<0.05)$.

\begin{tabular}{|c|c|c|c|c|c|c|c|c|}
\hline & Ajaccio1 & Ajaccio2 & Bonifacio1 & Bonifacio2 & SaintFlorent1 & SaintFlorent2 & Calvi1 & Calvi2 \\
\hline $\mathrm{Ag}$ & $0.02( \pm 0.01)^{\mathrm{c}}$ & $0.12( \pm 0.02)^{\mathrm{ab}}$ & $0.03( \pm 0.01)^{\mathrm{c}}$ & $0.02( \pm 0.01)^{\mathrm{c}}$ & $0.27( \pm 0.11)^{\mathrm{a}}$ & $0.08( \pm 0.01)^{\mathrm{b}}$ & $0.09( \pm 0.01)^{b}$ & $0.23( \pm 0.06)^{\mathrm{a}}$ \\
\hline $\mathrm{Al}$ & $85.56( \pm 16.07)^{\mathrm{a}}$ & $38.67( \pm 7.65)^{\mathrm{abc}}$ & $24.17( \pm 9.73)^{\mathrm{cde}}$ & $28.47( \pm 6.59)^{\mathrm{cde}}$ & $13.29( \pm 2.72)^{\mathrm{bcd}}$ & $49.4( \pm 10.94)^{\mathrm{ab}}$ & $13.27( \pm 6.06)^{\mathrm{e}}$ & $10.08( \pm 1.88)^{\mathrm{e}}$ \\
\hline As & $26.67( \pm 1.27)^{\mathrm{cd}}$ & $24.06( \pm 1.89)^{\mathrm{cd}}$ & $35.25( \pm 4.03)^{\mathrm{bc}}$ & $20.97( \pm 2.32)^{d}$ & $59.41( \pm 5.43)^{\mathrm{a}}$ & $56.71( \pm 5.97)^{\mathrm{a}}$ & $33.58( \pm 2.24)^{\mathrm{bc}}$ & $45.60( \pm 5.15)^{\mathrm{ab}}$ \\
\hline $\mathrm{Ba}$ & $0.47( \pm 0.07)^{\mathrm{a}}$ & $0.43( \pm 0.07)^{\mathrm{ab}}$ & $0.24( \pm 0.09)^{\mathrm{cd}}$ & $0.34( \pm 0.06)^{a b c}$ & $0.14( \pm 0.01)^{d}$ & $0.18( \pm 0.02)^{\mathrm{cd}}$ & $0.25( \pm 0.06)^{\mathrm{bcd}}$ & $0.35( \pm 0.09)^{\mathrm{abc}}$ \\
\hline $\mathrm{Cd}$ & $0.08( \pm 0.01)^{\mathrm{d}}$ & $0.13( \pm 0.01)^{\mathrm{bcd}}$ & $0.16( \pm 0.01)^{\mathrm{bc}}$ & $0.12( \pm 0.02)^{\mathrm{cd}}$ & $0.38( \pm 0.04)^{\mathrm{a}}$ & $0.48( \pm 0.09)^{\mathrm{a}}$ & $0.18( \pm 0.02)^{b}$ & $0.35( \pm 0.03)^{\mathrm{a}}$ \\
\hline Co & $0.14( \pm 0.01)^{\mathrm{cd}}$ & $0.25( \pm 0.03)^{\mathrm{bc}}$ & $0.21( \pm 0.03)^{\mathrm{bcd}}$ & $0.26( \pm 0.03)^{\mathrm{bc}}$ & $0.28( \pm 0.04)^{b}$ & $1.36( \pm 0.17)^{\mathrm{a}}$ & $0.12( \pm 0.01)^{d}$ & $0.30( \pm 0.04)^{\mathrm{b}}$ \\
\hline $\mathrm{Cr}$ & $0.39( \pm 0.05)^{\mathrm{c}}$ & $0.58( \pm 0.08)^{\mathrm{bc}}$ & $0.56( \pm 0.09)^{\mathrm{bc}}$ & $0.68( \pm 0.12)^{\mathrm{bc}}$ & $0.98( \pm 0.17)^{b}$ & $4.08( \pm 0.85)^{\mathrm{a}}$ & $0.37( \pm 0.05)^{\mathrm{c}}$ & $0.79( \pm 0.14)^{\mathrm{c}}$ \\
\hline $\mathrm{Cu}$ & $4.56( \pm 0.17)^{\mathrm{a}}$ & $4.09( \pm 0.12)^{\mathrm{ab}}$ & $3.65( \pm 0.13)^{\mathrm{bc}}$ & $4.70( \pm 0.17)^{\mathrm{a}}$ & $3.54( \pm 0.11)^{\mathrm{bc}}$ & $3.46( \pm 0.17)^{\mathrm{c}}$ & $3.57( \pm 0.18)^{\mathrm{bc}}$ & $3.557( \pm 0.14)^{\mathrm{bc}}$ \\
\hline $\mathrm{Fe}$ & $115.08( \pm 15.62)^{\mathrm{a}}$ & $95.21( \pm 11.84)^{\mathrm{ab}}$ & $59.49( \pm 11.89)^{\mathrm{bc}}$ & $52.03( \pm 7.59)^{\mathrm{bc}}$ & $37.39( \pm 6.82)^{\mathrm{c}}$ & $237.88( \pm 45.96)^{\mathrm{a}}$ & $46.84( \pm 10.61)^{c}$ & $38.79( \pm 5.18)^{c}$ \\
\hline $\mathrm{Li}$ & $0.32( \pm 0.01)^{\mathrm{a}}$ & $0.32( \pm 0.02)^{\mathrm{a}}$ & $0.32( \pm 0.02)^{\mathrm{a}}$ & $0.30( \pm 0.01)^{\mathrm{a}}$ & $0.29( \pm 0.01)^{\mathrm{a}}$ & $0.36( \pm 0.02)^{\mathrm{a}}$ & $0.34( \pm 0.02)^{\mathrm{a}}$ & $0.35( \pm 0.02)^{\mathrm{a}}$ \\
\hline Mn & $3.04( \pm 0.28)^{\mathrm{ab}}$ & $2.50( \pm 0.19)^{\mathrm{abc}}$ & $1.66( \pm 0.19)^{\mathrm{d}}$ & $2.24( \pm 0.17)^{\mathrm{abcd}}$ & $1.69( \pm 0.13)^{\mathrm{cd}}$ & $3.48( \pm 0.49)^{\mathrm{a}}$ & $1.53( \pm 0.13)^{\mathrm{d}}$ & $1.93( \pm 0.15)^{b c d}$ \\
\hline Mo & $0.23( \pm 0.03)^{\mathrm{b}}$ & $0.32( \pm 0.02)^{\mathrm{ab}}$ & $0.33( \pm 0.04)^{\mathrm{ab}}$ & $0.37( \pm 0.04)^{\mathrm{a}}$ & $0.37( \pm 0.03)^{\mathrm{a}}$ & $0.42( \pm 0.05)^{\mathrm{a}}$ & $0.30( \pm 0.03)^{\mathrm{ab}}$ & $0.36( \pm 0.04)^{\mathrm{ab}}$ \\
\hline $\mathrm{Ni}$ & $0.22( \pm 0.03)^{\mathrm{b}}$ & $0.46( \pm 0.07)^{\mathrm{b}}$ & $0.30( \pm 0.06)^{\mathrm{b}}$ & $0.44( \pm 0.08)^{\mathrm{b}}$ & $0.50( \pm 0.09)^{b}$ & $5.25( \pm 1.34)^{\mathrm{a}}$ & $0.33( \pm 0.03)^{\mathrm{b}}$ & $0.39( \pm 0.06)^{b}$ \\
\hline $\mathrm{Pb}$ & $0.17( \pm 0.02)^{\mathrm{bc}}$ & $0.50( \pm 0.26)^{\mathrm{ab}}$ & $0.16( \pm 0.02)^{\mathrm{bc}}$ & $0.39( \pm 0.06)^{\mathrm{a}}$ & $0.11( \pm 0.01)^{\mathrm{c}}$ & $0.09( \pm 0.01)^{\mathrm{c}}$ & $0.12( \pm 0.01)^{\mathrm{c}}$ & $0.11( \pm 0.01)^{\mathrm{c}}$ \\
\hline $\mathrm{Sb}$ & $0.16( \pm 0.02)^{\mathrm{ab}}$ & $0.15( \pm 0.03)^{\mathrm{abc}}$ & $0.34( \pm 0.10)^{\mathrm{a}}$ & $0.18( \pm 0.02)^{\mathrm{ab}}$ & $0.10( \pm 0.01)^{\mathrm{bc}}$ & $0.27( \pm 0.16)^{\mathrm{bc}}$ & $0.06( \pm 0.01)^{\mathrm{c}}$ & $0.06( \pm 0.01)^{\mathrm{c}}$ \\
\hline $\mathrm{Se}$ & $1.78( \pm 0.10)^{\mathrm{a}}$ & $1.76( \pm 0.10)^{\mathrm{a}}$ & $2.19( \pm 0.22)^{\mathrm{a}}$ & $2.03( \pm 0.23)^{\mathrm{a}}$ & $1.96( \pm 0.16)^{\mathrm{a}}$ & $2.35( \pm 0.28)^{\mathrm{a}}$ & $1.62( \pm 0.11)^{\mathrm{a}}$ & $2.186( \pm 0.125)^{\mathrm{a}}$ \\
\hline Sn & $0.01( \pm 0.01)^{\mathrm{b}}$ & $0.02( \pm 0.01)^{\mathrm{b}}$ & $0.05( \pm 0.01)^{\mathrm{a}}$ & $0.02( \pm 0.01)^{\mathrm{b}}$ & $0.01( \pm 0.01)^{\mathrm{c}}$ & $0.01( \pm 0.01)^{\mathrm{c}}$ & $0.01( \pm 0.01)^{\mathrm{c}}$ & $0.02( \pm 0.01)^{\mathrm{bc}}$ \\
\hline $\mathrm{U}$ & $0.43( \pm 0.07)^{\mathrm{c}}$ & $0.67( \pm 0.08)^{\mathrm{bc}}$ & $0.94( \pm 0.24)^{\mathrm{bc}}$ & $0.74( \pm 0.11)^{\mathrm{bc}}$ & $1.75( \pm 0.29)^{\mathrm{a}}$ & $1.61( \pm 0.33)^{\mathrm{a}}$ & $0.64( \pm 0.12)^{\mathrm{bc}}$ & $1.11( \pm 0.16)^{\mathrm{ab}}$ \\
\hline $\mathrm{V}$ & $1.93( \pm 0.27)^{\mathrm{b}}$ & $2.82( \pm 0.42)^{\mathrm{ab}}$ & $2.92( \pm 0.64)^{\mathrm{ab}}$ & $2.53( \pm 0.47)^{\mathrm{ab}}$ & $4.62( \pm 0.83)^{a}$ & $5.05( \pm 0.75)^{\mathrm{a}}$ & $1.65( \pm 0.32)^{b}$ & $3.18( \pm 0.49)^{\mathrm{ab}}$ \\
\hline $\mathrm{Zn}$ & $201.82( \pm 54.30)^{\mathrm{a}}$ & $304.12( \pm 76.44)^{\mathrm{a}}$ & $195.16( \pm 42.68)^{\mathrm{a}}$ & $133.24( \pm 30.64)^{\mathrm{a}}$ & $192.98( \pm 48.40)^{\mathrm{a}}$ & $192.23( \pm 78.61)^{\mathrm{a}}$ & $115.90( \pm 25.25)^{\mathrm{a}}$ & $231.93( \pm 53.51)^{\mathrm{a}}$ \\
\hline
\end{tabular}


Table 3

Trace Element Spatial Variation Index (TESVI) of 20 TE examined in $P$. lividus from 8 stations in Corsica Island. The higher the TESVI value the greater the spatial variation of that element among the sampling locations.

\begin{tabular}{lllll}
\hline $\mathrm{TE}$ & $\left(x_{\max } / x_{\min }\right)$ & $\Sigma\left(x_{\max } / x_{i}\right) / \mathrm{n} \pm \mathrm{SD}$ & TESVI & Station $x_{\max }$ \\
\hline $\mathrm{Ag}$ & 11.30 & $4.81 \pm 4.04$ & 9.49 & $\mathrm{SF} 1$ \\
$\mathrm{Al}$ & 8.48 & $4.11 \pm 2.69$ & 5.55 & $\mathrm{~A} 1$ \\
$\mathrm{As}$ & 2.83 & $1.79 \pm 0.67$ & 1.06 & $\mathrm{SF} 1$ \\
$\mathrm{Ba}$ & 3.38 & $1.83 \pm 0.81$ & 1.50 & $\mathrm{~A} 1$ \\
$\mathrm{Cd}$ & 5.73 & $2.84 \pm 1.62$ & 3.28 & $\mathrm{SF} 2$ \\
$\mathrm{Co}$ & 11.37 & $5.97 \pm 3.14$ & 5.98 & $\mathrm{SF} 2$ \\
$\mathrm{Cr}$ & 10.88 & $6.45 \pm 3.21$ & 5.41 & $\mathrm{SF} 2$ \\
$\mathrm{Cu}$ & 1.36 & $1.22 \pm 0.14$ & 0.16 & $\mathrm{~B} 2$ \\
$\mathrm{Fe}$ & 6.36 & $3.96 \pm 1.95$ & 3.13 & $\mathrm{SF} 2$ \\
$\mathrm{Li}$ & 1.26 & $1.12 \pm 0.09$ & 0.10 & $\mathrm{SF} 2$ \\
$\mathrm{Mn}$ & 2.26 & $1.66 \pm 0.46$ & 0.63 & $\mathrm{SF} 2$ \\
$\mathrm{Mo}$ & 1.79 & $1.29 \pm 0.24$ & 0.34 & $\mathrm{SF} 2$ \\
$\mathrm{Ni}$ & 23.77 & $13.02 \pm 6.49$ & 11.84 & $\mathrm{SF} 2$ \\
$\mathrm{~Pb}$ & 5.14 & $3.31 \pm 1.55$ & 2.40 & A2 \\
$\mathrm{Sb}$ & 5.77 & $2.89 \pm 1.83$ & 3.65 & $\mathrm{~B} 1$ \\
$\mathrm{Se}$ & 1.45 & $1.20 \pm 0.15$ & 0.19 & SF2 \\
$\mathrm{Sn}$ & 11.20 & $5.28 \pm 4.01$ & 8.51 & $\mathrm{~B} 1$ \\
$\mathrm{U}$ & 4.08 & $2.16 \pm 1.01$ & 1.91 & SF1 \\
$\mathrm{V}$ & 3.07 & $1.86 \pm 0.70$ & 1.16 & SF2 \\
$\mathrm{Zn}$ & 2.62 & $1.68 \pm 0.52$ & 0.82 & A2 \\
\hline
\end{tabular}

gonads. It appears that no study on $P$. lividus has analyzed so many TE (20) in a Mediterranean region. For many of these studies (especially those on emerging elements), the comparison with other sites is therefore impossible, but our data are essential and will serve as a reference state to follow the evolution of these elements in the Mediterranean ecosystems. The analysis of contaminants accumulated in sea urchin gonads allowed us to calculate a global pollution index. TEPI is used here as a tool that allows a reliable comparison of TE contamination, both locally and internationally, regardless of the number of TE used or the biological model (Wilkes et al., 2017). Trace element contamination is widespread in the Mediterranean Sea with nearly half of the study sites showing high concentrations. The TEPI carried out revealed spatial differences in contamination. As previously described by Richir et al. (2015), TE contamination in the western Mediterranean overall displayed a north-to-south gradient, from the Italian coasts down through the insular Corsican coasts to the north African littoral. Based on the available data, the western (Algeria, Spain) and eastern (Greece) basins of the Mediterranean seem to be contamination hotspots with almost all stations classed in HCL sites. On the other hand, the central area between continental French coasts, Corsica Island,
Table 4

Comparison of calculated TEPI values from different studies published in the Mediterranean Sea in P. lividus. LCL is the low contamination level, MCL is the medium contamination level, and HCL is the high contamination level.

\begin{tabular}{|c|c|c|c|c|}
\hline Country & Station & TEPI & Quality scale & Reference \\
\hline \multirow[t]{9}{*}{ Algeria } & Algiers Beach & 0.930 & HCL & Soualili et al., 2008 \\
\hline & Tamentfoust & 0.771 & HCL & \\
\hline & Sidi-Fredj & 0.611 & MCL & \\
\hline & Sidi Mejdoub & 1.513 & HCL & Guendouzi et al., 2017 \\
\hline & Abdelmalek & 1.261 & HCL & \\
\hline & Bateau Cassé & 1.452 & HCL & \\
\hline & Oran & 1.523 & HCL & Rouane-Hacene et al., 2017 \\
\hline & Ain Defla & 0.916 & HCL & \\
\hline & Hadjaj & 0.741 & HCL & \\
\hline \multirow[t]{9}{*}{ France } & Marseille & 0.561 & MCL & Warnau et al., 1998 \\
\hline & Ajaccio1 & 0.549 & MCL & Our study \\
\hline & Ajaccio2 & 0.701 & HCL & \\
\hline & Calvi1 & 0.441 & LCL & \\
\hline & Calvi2 & 0.638 & MCL & \\
\hline & Saint-Florent1 & 0.621 & MCL & \\
\hline & Saint-Florent2 & 1.034 & HCL & \\
\hline & Bonifacio1 & 0.623 & MCL & \\
\hline & Bonifacio2 & 0.591 & MCL & \\
\hline \multirow[t]{22}{*}{ Italy } & Ischia Island & 0.954 & HCL & Warnau et al., 1998 \\
\hline & Apulian coast & 0.880 & HCL & Storelli et al., 2001 \\
\hline & Pianosa & 0.732 & HCL & Pinsino et al., 2008 \\
\hline & Caprara & 0.701 & MCL & \\
\hline & Syracuse & 0.515 & LCL & Salvo et al., 2014 \\
\hline & Raguse & 0.391 & LCL & \\
\hline & Messina & 0.641 & MCL & \\
\hline & Milazzo & 0.928 & HCL & \\
\hline & Priolo & 1.663 & HCL & \\
\hline & Gela & 0.749 & HCL & \\
\hline & Brolo & 0.221 & LCL & \\
\hline & Catania & 0.051 & LCL & \\
\hline & Filicudi & 0.099 & LCL & \\
\hline & Civitavecchia1 & 0.704 & HCL & Scanu et al., 2015 \\
\hline & Civitavecchia2 & 0.218 & LCL & \\
\hline & Civitavecchia3 & 0.070 & LCL & \\
\hline & Civitavecchia4 & 0.688 & MCL & \\
\hline & Civitavecchia5 & 0.225 & LCL & \\
\hline & Civitavecchia6 & 0.527 & MCL & \\
\hline & Civitavecchia7 & 0.605 & MCL & \\
\hline & Civitavecchia8 & 0.159 & LCL & \\
\hline & Civitavecchia9 & 0.451 & LCL & \\
\hline \multirow[t]{5}{*}{ Greece } & Akoli & 1.992 & HCL & Portocali et al., 1997 \\
\hline & Patras & 0.860 & HCL & \\
\hline & Agios Thomas & 1.301 & HCL & Strogyloudi et al., 2014 \\
\hline & Koronisia & 1.184 & HCL & \\
\hline & Mytikas & 1.309 & HCL & \\
\hline Spain & Mallorca & 0.843 & HCL & Deudero et al., 2007 \\
\hline
\end{tabular}

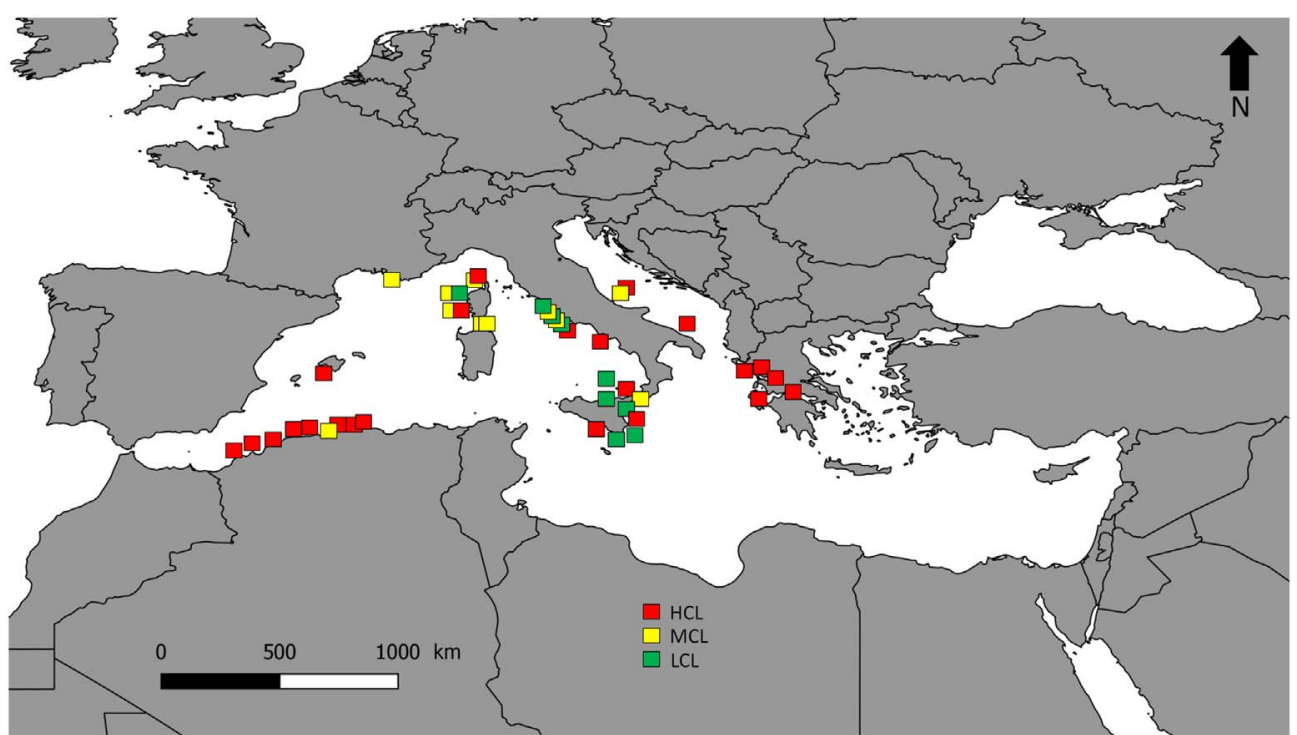

Fig. 2. Map showing the visual interpretation of TE contamination based on the TEPI from various geographical locations. LCL is the low contamination level, MCL is the medium contamination level, and HCL is the high contamination level. Data from Algeria (Guendouzi et al., 2017; Rouane-Hacene et al., 2017; Soualili et al., 2008), France (our study, Warnau et al., 1998), Italy (Pinsino et al., 2008; Salvo et al., 2014; Scanu et al., 2015; Storelli et al., 2001; Warnau et al., 1998), Greece (Portocali et al., 1997; Strogyloudi et al., 2014), and Spain: (Deudero et al., 2007). 
continental Italian coasts, and Sicily Island presents a heterogeneity resulting in sites with varying degrees of contamination. The present study has shown that a region as pristine as Corsica can be subject to significant anthropogenic pressures that influence local TE contamination levels. Indeed, in Corsica we find a wide range of types of pressure and environmental conditions representative of the western Mediterranean region (Lafabrie et al., 2008; Lopez y Royo et al., 2009).

In Corsica, two stations (Ajaccio2 and Saint Florent2) are referenced as HCL sites with important concentrations in $\mathrm{Zn}, \mathrm{Fe}, \mathrm{As}, \mathrm{Al}$, and $\mathrm{Cu}$. The calculated TEPI can be related to some contamination levels reported from other Mediterranean coasts [for example: Algeria (Guendouzi et al., 2017), Greece (Strogyloudi et al., 2014), Italy (Scanu et al., 2015), and Spain (Deudero et al., 2007)]. In our study, the observed concentrations and low TESVI define $\mathrm{Zn}$ as the dominant TE both in these HCL sites and in the whole study area. Concentration magnitudes of $\mathrm{Zn}$ are of the same order as those observed elsewhere in the Mediterranean (Guendouzi et al., 2017; Soualili et al., 2008; Storelli et al., 2001; Warnau et al., 1998). Zn is an essential element for reproduction (Ahn et al., 2009), explaining generally high concentrations in all, but especially female, gonads. Urban sewage is considered as a potential source of $\mathrm{Zn}$ contamination (Portocali et al., 1997), which is in accordance with our results. Indeed, the highest concentrations of the TE were observed in Ajaccio2, the wastewater treatment plant of Ajaccio city.

TE such as $\mathrm{Fe}, \mathrm{Al}, \mathrm{As}$, and $\mathrm{Cu}$, observed in high concentration in the present study are also representative of anthropogenic contamination, showing that HCL sites are influenced by domestic and/or industrial discharges. In contrast other studies (Guendouzi et al., 2017; RouaneHacene et al., 2017; Scanu et al., 2015; Warnau et al., 1998), our results show very low $\mathrm{Pb}$ concentration levels in Corsica, although they are quite common in industrial and harbor effluents (antifouling point, fuels, etc.).

The second HCL station in Corsica (Saint Florent2) is close to a former asbestos mine. The TE contamination in sea urchin gonads from this site is characterized by similar $\mathrm{Zn}, \mathrm{Fe}, \mathrm{As}$, and $\mathrm{Al}$ concentrations as in Ajaccio2. The difference between these two sites is the presence of three TE specific to the site indicated by high TESVI: Ni, Cr, and Co. These elements, as well as iron and manganese, associated with the amiantiferous serpentine deposit have been released at sea and continue to fuel the coastline through the leaching of tailings still present on the flanks of the mine (Andral et al., 2004; Galgani et al., 2006). Bouchoucha et al. (2012) reported heavier Ni and Cr levels in sea urchin gonads than those found in our study, probably due to the sample sites closer to the asbestos mine.

Five stations are classed as medium contamination levels (MCL) sites. With lower concentrations of $\mathrm{Zn}, \mathrm{Fe}, \mathrm{As}, \mathrm{Al}$ and $\mathrm{Cu}, \mathrm{MCL}$ sites have two marked typologies. While two of them, close to commercial harbor and leisure marina (Bonifacio2 and Calvi2), are clearly influenced by anthropogenic activities, three other stations (Saint Florent1, Bonifacio1, Ajaccio1) are natural sites without an apparent source of contamination. However, each of these last stations is marked by a specific trace element (high TESVI): Ag for Saint Florent1, Al for Ajaccio1, and Sn for Bonifacio1. The TEPI indicated other coastal MCL sites. For most of them, the sources of contamination are clearly established and include harbor activities and urban, agricultural, and industrial discharges. Natural sites with no defined contamination source are uncommon; only the Capara site, a protected marine area in Italy, is described (Pinsino et al., 2008).

A single station, Calvi1, is specified as a Low Contamination Level (LCL) site due to the relatively clean homogenous status of the water body of the Calvi Bay area. All TE have a lower concentration here than in other sites and none of these have high TESVI. These LCL stations are usually distant from the source of contamination, with a surprising exception for Civitavecchia (Italy) or Catania (Sicily) sites which have low contaminations despite their close proximity to well-known harbor activities (Salvo et al., 2014; Scanu et al., 2015).
Because of its sedentary lifestyle, $P$. lividus has often been described as an indicator of local pollution (Warnau et al., 1998; Bayed et al., 2005). The assessment of TE levels in sea urchin gonads clearly confirmed this hypothesis, showing local contaminations even within a preserved area such as Corsica. This region is impacted by many sources of contamination (e.g. harbors, mines, and sewage effluents) representative of pressures found at the Mediterranean scale and may in the future serve as a new comparison area to monitor the spatial and temporal variations of contamination. A better understanding of these pressures will allow managers to act at the source and reduce the degradation or improve the ecological quality of water bodies (Blanfuné et al., 2017). As proposed by Govers et al. (2014), from a research perspective, it could be interesting to study the importance of seasonality and physiological status for the use of sea urchins and other marine organisms as bioindicators for TE pollution.

\section{Acknowledgements}

The authors are grateful to the scuba diver team of the UMS 3514 Stella Mare from the University of Corsica for their efforts during the underwater sampling and for providing the necessary facilities. This publication is part of the MARE publication series and the FOCUS number is MARExxx.

\section{References}

Ahn, I., Ji, J., Park, H., 2009. Metal accumulation in sea urchins and their kelp diet in artic fjord (Kongsfjorden, Svalbard). Mar. Pollut. Bull. 58, 1571-1577.

Andral, B., Chiffoleau, J.F., Galgani, F., Tomasino, C., Emery, E., Pluquet, F., Thebault, H., 2004. Evaluation de la contamination chimique du site de Canari: campagne Canari II. Rapport d'étude à l'Office de l'Environnement Corse; convention n 2002/358.

Bayed, A., Quiniou, F., Benrha, A., Guillou, M., 2005. The Paracentrotus lividus populations from the northern Moroccan Atlantic coast: growth, reproduction and health condition. J. Mar. Biol. Assoc. U. K. 85, 999-1007.

Belabed, B.E., Laffray, X., Dhib, A., Fertouna-Belakhal, M., Turki, S., Aleya, L., 2013. Factors contributing to heavy metal accumulation in sediments and in the intertidal mussel Perna perna in the Gulf of Annaba (Algeria). Mar. Pollut. Bull. 74, 477-489.

Blanfuné, A., Thibaut, T., Boudouresque, C.F., Mačić, V., Markovic, L., Palomba, L., Boissery, P., 2017. The CARLIT method for the assessment of the ecological quality of European Mediterranean waters: relevance, robustness and possible improvements. Ecol. Indic. 72, 249-259.

Bonanno, G., Di Martino, V., 2017. Trace element compartmentation in the seagrass Posidonia oceanica and biomonitoring applications. Mar. Pollut. Bull. 116, 196-203.

Bouchoucha, M., Galgani, F., Andral, B., Baldi, Y., Chiffoleau, J.F., Auger, D., Rozuel, E., 2012. Evaluation des risques sanitaires et environnementaux liés à la contamination du Golfe de Saint-Florent par les métaux lourds - Etude CANARI III. Rapport d'étude à l'Office de l'Environnement Corse; Convention n 04/008.

Campanella, L., Conti, M.E., Cubadda, F., Sucapane, C., 2001. Trace metals in seagrass, algae and molluscs from an uncontaminated area in the Mediterranean. Environ. Pollut. 111, 117-126.

Currie, L.A., 1999. Nomenclature in evaluation of analytical methods including detection and quantification capabilities1: (IUPAC recommendations 1995). Anal. Chim. Acta $391,105-126$.

Deudero, S., Box, A., March, D., Valencia, J.M., Grau, A.M., Tintore, J., Benedicto, J., 2007. Temporal trends of metals in benthic invertebrate species from the Balearic Islands, Western Mediterranean. Mar. Pollut. Bull. 54, 1545-1558.

Galgani, F., Chiffoleau, J.-F., Orsoni, V., Costantini, L., Boissery, P., Calendini, S., Andral, B., 2006. Chemical contamination and sediment toxicity along the coast of Corsica. Chem. Ecol. 22, 299-312.

Gharred, T., Ezzine, I.K., Naija, A., Bouali, R.R., Jebali, J., 2015. Assessment of toxic interactions between deltamethrin and copper on the fertility and developmental events in the Mediterranean sea urchin, Paracentrotus lividus. Environ. Monit. Assess. 187, 193.

Gobert, S., Pasqualini, V., Dijoux, J., Lejeune, P., Durieux, E.D., Marengo, M., 2017. Trace element concentrations in the apex predator swordfish (Xiphias gladius) from a Mediterranean fishery and risk assessment for consumers. Mar. Pollut. Bull. 120, 364-369.

Govers, L.L., Lamers, L.P.M., Bouma, T.J., Eygensteyn, J., de Brouwer, J.H.F., Hendriks, A.J., van Katwijk, M.M., 2014. Seagrasses as indicators for coastal trace metal pollution: a global meta-analysis serving as a benchmark, and a Caribbean case study. Environ. Pollut. 195, 210-217.

Guendouzi, Y., Soualili, D.L., Boulahdid, M., Boudjenoun, M., Mezali, K., 2017. Seasonal variation in bioavailability of trace metals in the echinoid Paracentrotus lividus (Lamarck, 1816) from Algerian coastal waters: effect of physiological indices. Reg. Stud. Mar. Sci. 14, 112-117.

Hambidge, K.M., Casey, C.E., Krebs, N.F., 1986. Zinc. In: Mertz, W. (Ed.), Trace Elements in Human and Animal Nutrition, 5th ed. Academic Press, New York, NY, pp. 1-37. Lafabrie, C., Pergent-Martini, C., Pergent, G., 2008. Metal contamination of Posidonia 
oceanica meadows along the Corsican coastline (Mediterranean). Environ. Pollut. $151,262-268$.

Lopez y Royo, C., Silvestri, C., Salivas-Decaux, M., Pergent, G., Casazza, G., 2009. Application of an angiosperm-based classification system (BiPo) to Mediterranean coastal waters: using spatial analysis and data on metal contamination of plants in identifying sources of pressure. Hydrobiologia 633, 169-179.

Morrison, L., Bennion, M., McGrory, E., Hurley, W., Johnson, M.P., 2017. Talitrus saltator as a biomonitor: an assessment of trace element contamination on an urban coastline gradient. Mar. Pollut. Bull. 120, 232-238.

Pinsino, A., Della Torre, C., Sammarini, V., Bonaventura, R., Amato, E., Matranga, V., 2008. Sea urchin coelomocytes as a novel cellular biosensor of environmental stress: a field study in the Tremiti Island Marine Protected Area, Southern Adriatic Sea, Italy. Cell Biol. Toxicol. 24, 541-552.

Portocali, Ph., Iliopoulou-Georgudaki, J., Catsiki, V.A., Papapetropoulou, M., 1997. The role of echinoderms as bioindicators of seawater pollution: a case study from patraicos and corinthiacos Gulf, N. Peloponnesus, Greece. Toxicol. Environ. Chem. 59, 293-303.

Richir, J., Gobert, S., 2014. A reassessment of the use of Posidonia oceanica and Mytilus galloprovincialis to biomonitor the coastal pollution of trace elements: new tools and tips. Mar. Pollut. Bull. 89, 390-406.

Richir, J., Gobert, S., 2016. Trace elements in marine environments: occurrence, threats and monitoring with special focus on the coastal Mediterranean. J. Environ. Anal. Toxicol. 6 (1).

Richir, J., Salivas-Decaux, M., Lafabrie, C., Lopez y Royo, C., Gobert, S., Pergent, G., Pergent-Martini, C., 2015. Bioassessment of trace element contamination of Mediterranean coastal waters using the seagrass Posidonia oceanica. J. Environ. Manag. 151, 486-499.

Rouane-Hacene, O., Boutiba, Z., Benaissa, M., Belhaouari, B., Francour, P., GuibboliniSabatier, M.E., Risso-De Faverney, C., 2017. Seasonal assessment of biological indices, bioaccumulation, and bioavailability of heavy metals in sea urchins Paracentrotus lividus from Algerian west coast, applied to environmental monitoring. Environ. Sci. Pollut. Res. 1-14.

Ruocco, N., Costantini, M., Santella, L., 2016. New insights into negative effects of lithium on sea urchin Paracentrotus lividus embryos. Sci. Rep. 6, 32157.

Salomidi, M., Katsanevakis, S., Borja, A., Braeckman, U., Damalas, D., Galparsoro, I., Mifsud, R., Mirto, S., Pascual, M., Pipitone, C., Rabaut, M., Todorova, V., Vassilopoulou, V., Vega Fernandez, T., 2012. Assessment of goods and services, vulnerability, and conservation status of European seabed biotopes: a stepping stone towards ecosystem-based marine spatial management. Mediterr. Mar. Sci. 13, 49-88. Salvo, A., Potortì, A.G., Cicero, N., Bruno, M., Turco, V.L., Bella, G.D., Dugo, G., 2014. Statistical characterisation of heavy metal contents in Paracentrotus lividus from Mediterranean Sea. Nat. Prod. Res. 28, 718-726.

Salvo, A., Cicero, N., Vadalà, R., Mottese, A.F., Bua, D., Mallamace, D., Giannetto, C., Dugo, G., 2016. Toxic and essential metals determination in commercial seafood: Paracentrotus lividus by ICP-MS. Nat. Prod. Res. 30, 657-664.

Scanu, S., Soetebier, S., Piazzolla, D., Tiralongo, F., Mancini, E., Romano, N., Marcelli, M., 2015. Concentrations of As, $\mathrm{Cd}, \mathrm{Cr}, \mathrm{Ni}$, and $\mathrm{Pb}$ in the echinoid Paracentrotus lividus on the coast of Civitavecchia, northern Tyrrhenian Sea, Italy. Reg. Stud. Mar. Sci. 1, $7-17$.

Serrano, O., Mateo, M.A., Dueñas-Bohórquez, A., Renom, P., López-Sáez, J.A., Cortizas, A.M., 2011. The Posidonia oceanica marine sedimentary record: a Holocene archive of heavy metal pollution. Sci. Total Environ. 409, 4831-4840.

Soualili, D., Dubois, P., Gosselin, P., Pernet, P., Guillou, M., 2008. Assessment of seawater pollution by heavy metals in the neighbourhood of Algiers: use of the sea urchin, Paracentrotus lividus, as a bioindicator. ICES J. Mar. Sci. 65, 132-139.

Storelli, M.M., Storelli, A., Marcotrigiano, G.O., 2001. Heavy metals in the aquatic environment of the Southern Adriatic Sea, Italy: macroalgae, sediments and benthic species. Environ. Int. 26, 505-509.

Strogyloudi, E., Pancucci-Papadopoulou, M.-A., Papadopoulos, G.L., 2014. Metal and metallothionein concentrations in Paracentrotus lividus from Amvrakikos gulf (Ionian Sea-Greece). Environ. Monit. Assess. 186, 5489-5499.

Unuma, T., Ikeda, K., Yamano, K., Moriyama, A., Ohta, H., 2007. Zinc-binding property of the major yolk protein in the sea urchin-implications of its role as a zinc transporter for gametogenesis. FEBS J. 274, 4985-4998.

Warnau, M., Biondo, R., Temara, A., Bouquegneau, J.-M., Jangoux, M., Dubois, P., 1998. Distribution of heavy metals in the echinoid Paracentrotus lividus from the Mediterranean Posidonia oceanica ecosystem: seasonal and geographical variations. J. Sea Res. 39, 267-280.

Wilkes, R., Bennion, M., McQuaid, N., Beer, C., McCullough-Annett, G., Colhoun, K., Morrison, L., 2017. Intertidal seagrass in Ireland: pressures, WFD status and an assessment of trace element contamination in intertidal habitats using Zostera noltei. Ecol. Indic. 82, 117-130.

Zhou, Q., Zhang, J., Fu, J., Shi, J., Jiang, G., 2008. Biomonitoring: an appealing tool for assessment of metal pollution in the aquatic ecosystem. Anal. Chim. Acta 606, $135-150$. 